\title{
Green Renewable Power and Policy in Canada: A Just Energy Transition to Net-Zero
}

\author{
Shirley Thompson \\ Natural Resources Institute, University of Manitoba, Winnipeg, Canada \\ Email:S.thompson@umanitoba.ca
}

How to cite this paper: Thompson, S. (2022). Green Renewable Power and Policy in Canada: A Just Energy Transition to Net-Zero. Journal of Geoscience and Environment Protection, 10, 1-12. https://doi.org/10.4236/gep.2022.103001

Received: January 8, 2022

Accepted: February 28, 2022

Published: March 3, 2022

Copyright $\odot 2022$ by author(s) and Scientific Research Publishing Inc. This work is licensed under the Creative Commons Attribution International License (CC BY 4.0).

http://creativecommons.org/licenses/by/4.0/ (c) (i) Open Access

\begin{abstract}
A just and sustainable future requires green renewable power. Net-zero by 2050 is the international goal to limit global warming to 1.5 degrees Celsius and sustain the biosphere. Green renewable energy, including wind, solar, biomass and small hydro is abundant in Canada, with potential to satisfy demand with $100 \%$ green renewables. This paper compares the renewable power landscape across Canada's provinces considering four factors-electricity energy mix, renewable energy targets (RETs), renewable energy standard offer programs (RESOPs), feed-in tariff (FITs) or community FITs (comFITs). The provinces with green renewable energy sources typically have enabling policies of RESOP, RETs and FITS, as Prince Edward Island, Nova Scotia, Ontario and New Brunswick do. In contrast, provinces with abundant oil and gas or large-scale hydro are without pro-renewable energy policies, nor community power options, excepting green renewables in Indigenous communities due to federal funding programs. Community green renewable power projects, such as the "Indigenous off-diesel initiative", are creating jobs, community revenue and energy sovereignty, towards just and inclusive energy in off-grid Indigenous communities. To reduce climate change, fast-tracking net-zero electricity by 2035 is recommended with the prioritization of community renewable energy by RESOPs, FITs and comFITs. For the transportation and other sectors, banning of all fossil fuels before 2040 is needed. Finally, a long-term plan to reduce the negative impacts of hydroelectricity water fluctuation is needed, considering decommissioning some dams.
\end{abstract}

\section{Keywords}

Feed-in-Tariffs, Renewable Energy, Energy Policy, Green Energy, Hydro-Development, Wind Energy

\section{Introduction}

Net-zero by 2050 is the international goal to limit global warming to 1.5 degrees 
Celsius, which requires green renewables for a just and inclusive transition (IEA, 2021). Green renewable energy power is necessary for sustainable development (Lappe, 2021; Lior, 2010; CREA, 2020). The growing number of disasters attributed to climate change requires the economy of Canada, as the fourth largest oil producer and the fourth largest hydroelectricity producer in the world, to transition to green renewable (Canada, 2022; IEA, 2021). Sixty percent of Canada's electrical share is generated from large-scale hydro development in 2020, which has unacceptable negative social and environmental impacts (IISD, 2022; IRENA, 2021).

Green renewables include biomass, solar, wind power or geothermal as well as small (<10 MW) hydro (USEPA, 2016). Green renewables offer a just and sustainable energy transition for communities and citizens by creating jobs, sharing revenue, securing energy and building capacity (UN, 2021) with the abundant renewable energy in Canada. Sixty percent of Canada's primary energy (electricity, transportation, heating/cooling, industry) is projected to be possible from wind alone by 2050 (CREA, 2020; CREA, 2016). Green renewable energy needs to expand if Canada is to attain net-zero energy. Canada's green renewable energy share grew from 2\% Canadian capacity in 2005 to $11 \%$ in 2015 and $13.6 \%$ in 2020 for wind and solar, making up 6\% energy generation (CREA, 2020).

Canada's provinces have many factors that impact green renewable electricity. This paper analyzes four factors important to shifting Canada towards green renewable electricity at the provincial level. This paper first describes how green renewable energy provides a just and inclusive energy transition to net-zero greenhouse gases (GHG). The method considers different economic, political and resource factors for their impact on provincial power transition to green renewables as shown in Figure 1. This model features four factors impacting the green renewable energy namely: renewable energy support programs (RESOPs), renewable energy targets, access to the grid through feed-in-tariffs (FITs) and the electricity energy mix. The results and discussion section compares the factors for each province. Finally, the conclusion provides an overall analysis of what factors drive green renewable energy across Canada to inform policy and recommendations towards a just and sustainable energy transition across Canada.

\subsection{Just and Sustainable Energy Transition}

To resist the large negative social and environmental impacts caused by major hydro dams and oil projects, a focus on just green renewable energy is needed to get to a net-zero future (IISD, 2022; TREC, 2016). Green renewable energy provides a pathway for just and sustainable community development and energy security (IRENA, 2021; IISD, 2022). Many Indigenous communities and some municipalities in Canada are showing leadership in renewable energy projects (ICE, 2022; IISD, 2022). Twenty years before the federal government's net-zero emission target for 2050, the small municipality of Halton Hills set a net-zero emissions target for 2030, requiring green renewables (Government of Canada, 
2021; Canada's National Observer, 2021). Also, remote Indigenous communities that generate electricity from diesel are transitioning to green renewables owned by the community (ICE, 2022).

The environmental and social impacts caused by fossil fuels and hydroelectricity need policy, programs and infrastructure to transition to a green economy (UN, 2021). Public policies are necessary to encourage investment in green renewables. A shift of mandate is needed for utilities to buy community energy generation (Dusyk et al., 2021). Crucial to green renewable development is investing in infrastructure using modern technologies, participation of stakeholders, and advancing a regional or distributed green energy market for achieving net-zero emission (UN, 2021). Green renewables are economically priced with their precipitous price drop (Silverstein, 2021), whereas large-scale hydro development is high cost which requires government financing (IISD, 2022).

Community energy generation offers decentralized power production located close to their service load, which increases energy security (Lior, 2010; IISD, 2022; Gregory, 2017; NEBC, 2016). For example, the renewable energy investment in remote and rural Indigenous communities, who suffer most from hydro development and economic poverty, provides revenues, job opportunities, energy security and community control over power generation (Kisik Clean Energy, 2022; Thompson, 2015). Green renewables provide distributed energy and local energy production, which limits the risks of downed transmission lines or pipeline disruption from climate change. Green renewables offer communities with energy security and community control, unlike big hydro, nuclear or oil and gas.

\subsection{Net-Zero Targets Role in the Green Renewable Energy Transition}

Canada's emission target plan for the year 2030 is still not in place in February 2022, although a net-zero target for GHG emission by 2050 has been codified by the Canadian Net-Zero Emissions Accountability Act (Government of Canada, 2021). This 2050 date is too slow according to many. A net-zero energy target for Canada's generation of electricity should be sooner, in 2035 according to the Pembina Institute (Dusyk et al., 2021). The European Union (EU) aims to implement legally binding targets of 55\% emission reduction by 2030 and zero emission of carbon by 2050 (Koval et al., 2021; Chestney et al., 2021).

Canada's national electrical supply can be provided through only green renewables. Scotland came very close to its $100 \%$ renewables target for electricity by 2020, which is the most ambitious in the European Union. Scotland had $96 \%$ renewables in 2020 and 99\% in 2021 (Sturgeon, 2021; Scottish Government, 2021) and a goal of net-zero emission by 2045 (Sturgeon, 2021). Scottish Renewables (2021) is a trade organization with 260 member organizations that "promotes the effective use of Scotland's abundant wind, wave, hydro, biomass, solar, landfill gas and tidal resources to generate social, economic and environmental benefits for all". With tens of thousands of workers in renewable energy, Scotland has successfully transitioned to renewable electricity, energy security and 
green jobs (Scottish Renewables, 2021). The many onshore wind turbines, offshore wind power, wave power, tidal power development and biomass generation projects are distributed throughout Scotland providing urban and rural job creation (Scottish Renewables, 2021). Green energy market incentives facilitated this transition but the market is changing as climate change targets are mandated (IEA, 2021).

Green renewables help countries meet their commitments for net-zero GHGs (IEA, 2021; Eckert \& Nasr, 2021) and adaptation to climate change. Climate change COP26-related targets require long-term commitments to limit global warming to 1.5 degrees Celsius. In line with the 2050 climate goals, Canada is committed to net-zero, which requires new renewable energy production. A just and inclusive transition to renewable energy requires a rapid deployment of green renewables. Renewables are defined as resources which regenerate within a generation. Hydro dams do not fit this definition due to the flooding and unnatural water fluctuations that negatively impact many generations (USEPA, 2016). The adverse effects, including mercury poisoning and permanent displacement from ancestral lands, are suffered disproportionately by Indigenous communities (NEBC, 2015; Thompson, 2015).

Hydroelectricity can be renewable or non-renewable based on its scale and impacts. Less than $10 \mathrm{MW}$ is considered renewable in the US, as at this scale social and environmental impacts are considered minimal (USEPA, 2016). The hydro generation above $10 \mathrm{MW}$ is not applicable towards a renewable energy standard in the US (USEPA, 2016). In contrast to the US EPA, the National Energy Board of Canada (NEBC, 2015) still considers large-scale hydro development to be renewable. Thus, we differentiate between renewable hydro for large hydro and green renewables for small hydro.

\section{Method}

For each province in Canada, fossil fuel and hydro generation amounts were compared to green renewable energy generation, analyzing their policies, programs and targets. A literature review included: Canada Energy Regulator (2021), Pembina Institute (Dusyk et al., 2021), Statista (2021a, 2021b, 2021c) and provincial government reports including Alberta Government (2021); Government of Ontario (2017); Nova Scotia Department of Energy (2021a, 2021b, 2021c); Nova Scotia Government (2020, 2021); Saskatchewan Chamber of Commerce (2019); and, SaskPower (2017). Figure 1 shows a model of how different factors impact renewable energy transition in Canada's provinces, considering options for community power. These factors are the existing energy mix, renewable energy standard offer program (RESOPs), renewable energy target (RETs), and access to the electrical grid by feed-in-tariffs (FITs), defined in this method.

\subsection{Electricity Energy Mix}

The electricity energy mix considers the primary energy sources. This analysis 


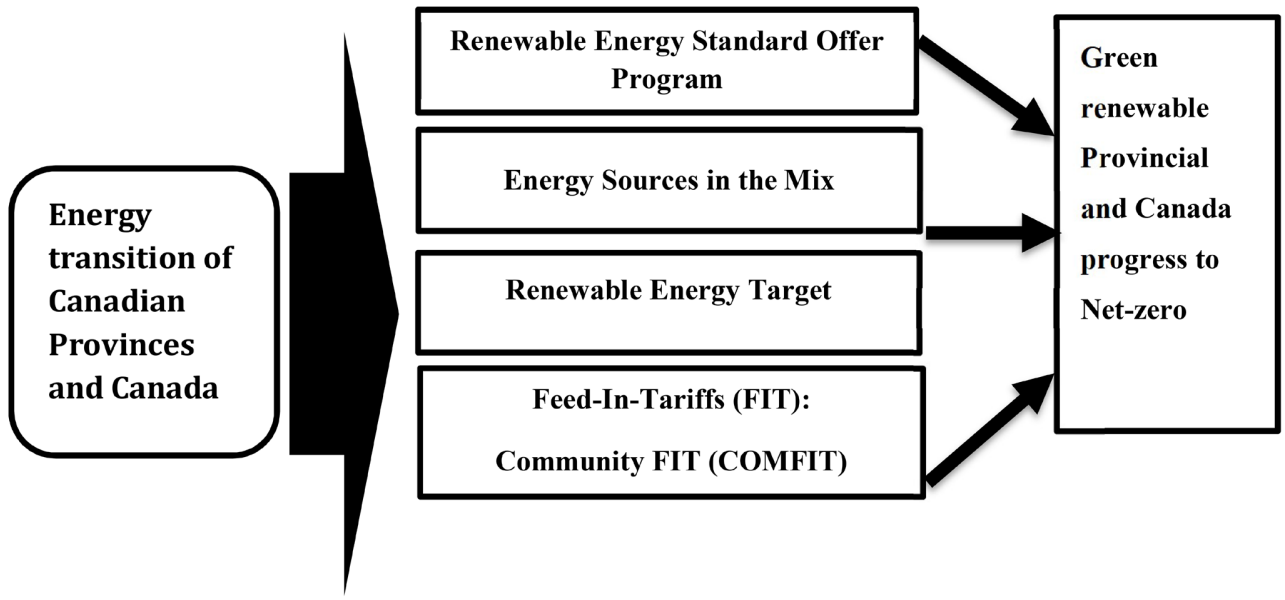

Figure 1. Conceptual frame for green renewable power and policy.

considers only electrical supply for each province, despite the need for net-zero energy in transportation and other sectors. The amounts and percent for each province for large hydro, biomass, solar and small hydro are listed in Table 1. The percent and changes for other non-renewables (coal, oil and nuclear) are easily deduced by subtracting the total for large hydro and green renewables from 100\% (Canada Energy Regulator, 2021).

\subsection{Renewable Energy Standard Offer Program (RESOP)}

Due to uncertainties in the new market of green renewables, a government remuneration plan that guarantees investors a return on investment is helpful (IISD, 2022). This remuneration plan is called a renewable energy standard offer program (RESOP), which standardizes long-term contracts and payment schedules for particular green renewable technologies. Remuneration plans offer a guaranteed price for various categories and capacities of renewable energy technologies to attract investment during technology development (Nova Scotia Department of Energy, 2021b).

A stable price for a set period for green renewable technologies is needed to provide an attractive investment opportunity. Alternatively, a request for proposals (RFPs) provides no price point or any green renewable energy purchase guarantee. The proponent must undertake investment and research in the RFP process, particularly in their early growth phase without any certainty about the project being able to advance where government controls development (Fraser, 2008; Nova Scotia Department of Energy, 2021c).

\subsection{Renewable Energy Target}

A renewable energy target is a renewable regulatory standard set by governments for energy generation by renewables (Dusyk et al., 2021). Unlike the electric energy mix, the only target available and provided in Table 1 considers all forms of energy, including heat generation and transportation, with Canada counting large-scale hydro as renewable. Targets require a certain fraction of energy generated 
Table 1. Renewable energy landscape across Canadian provinces for electricity production in 2018.

\begin{tabular}{|c|c|c|c|c|c|c|c|c|}
\hline \multirow{3}{*}{$\begin{array}{l}\text { Province } \\
\text { Canada }\end{array}$} & \multicolumn{5}{|c|}{ Amounts in 2018 of renewables in GigaWatts } & \multirow{3}{*}{ RESOP } & \multirow{3}{*}{ FIT } & \multirow{3}{*}{$\begin{array}{c}\text { Renewable Energy } \\
\text { Target percent\% } \\
\text { (year) }\end{array}$} \\
\hline & \multirow{2}{*}{ Big Hydro } & \multicolumn{3}{|c|}{ Green Renewables } & \multirow{2}{*}{ Total } & & & \\
\hline & & Wind & Bio-mass & Solar & & & & \\
\hline Ontario & $38,281(24.3 \%)$ & $11,964(7.6 \%)$ & $1500(1.0 \%)$ & $2988(1.9 \%)$ & $54,732(34.8 \%)$ & $\mathrm{X}$ & $\mathrm{X}^{*}$ & $50 \%$ RES (2023) \\
\hline Nova Scotia & $914(10.3 \%)$ & $1153(13.0 \%)$ & $251(2.8 \%)$ & 0 & $2319(26.1 \%)$ & $\mathrm{X}$ & \# & $80 \%$ RES (2030) \\
\hline New Bruns-Wick & $2535(20.4 \%)$ & $825(6.7 \%)$ & $438(3.5 \%)$ & 0 & $3797(30.6 \%)$ & $\mathrm{X}$ & $\mathrm{X}$ & 40\% RES (2020) \\
\hline $\begin{array}{l}\text { Prince Edward } \\
\text { Island }\end{array}$ & $\begin{array}{c}60 \% \text { energy } \\
\text { from NB }\end{array}$ & $640(98.9 \%)$ & $2(0.3 \%)$ & 0 & $642(99.2 \%)$ & $\mathrm{X}$ & $\mathrm{X}$ & 100\% RES (2030). \\
\hline Alberta & $1991(2.4 \%)$ & $4119(4.9 \%)$ & $1428(1.7 \%)$ & 0 & $7538(9.1 \%)$ & & & $30 \%$ RES (2030). \\
\hline NewfoundLand & 41,831 (95.2\%) & $206(0.5 \%)$ & 0 & 0 & $42,037(95.7 \%)$ & & & RES target (2050). \\
\hline Saskatchewan & $3591(15.2 \%)$ & $386(1.6 \%)$ & 0 & 0 & $3977(16.8 \%)$ & & & 50\% RES (2030) \\
\hline British Columbia & 61,791 (89.8\%) & $1724(2.5 \%)$ & $3837(5.6 \%)$ & 0 & $67,352(97.9 \%)$ & & * & No RES target \\
\hline Quebec & $199,783(94.3 \%)$ & $9955(4.7 \%)$ & $1252(0.6 \%)$ & 0 & $210,990(99.6 \%)$ & & * & 70\% RES (2025) \\
\hline Manitoba & $30,732(97.0 \%)$ & $873(2.8 \%)$ & $46(0.1 \%)$ & 0 & $31,651(99.9 \%)$ & & * & No RES target. \\
\hline
\end{tabular}

LEGEND: FIT-Feed-In Tariff, RESOP—Renewable Energy Standard Offer Program. ${ }^{\star}$ Indigenous community comFIT (community); "Nova Scotia ComFIT X > 500 kW FITS. Sources: Dusyk et al., 2021. Canada Energy Regulator, 2021, Provincial sources.

from renewable sources by a specific date, considering all generation including transportation and industry, heat and power. For Prince Edward Island (PEI), the percent of green renewables is inflated, as most of their energy is generated outside of this Province.

\subsection{Feed-in-Tariffs}

The feed-in tariff (FIT) is a key factor for green renewables as utility grid access is needed to take energy off-site. Since most provinces have provincial utilities that control grid access this is measureable. A FIT is a legislated requirement for public utilities to connect feasible energy projects. Public utility grid access is needed to facilitate renewable energy development (Dusyk et al., 2021; Mendonça et al., 2009).

The electrical public or private utility usually acts as a power generation monopoly by blocking access to the electrical power distribution. Grid access, enabled through the FIT, is critical for any renewable energy generation to distribute power. Green renewable energy growth results from the FIT enabling small-scale investment opportunities and reducing risk, particularly for communities and households, which are risk-averse (Dusyk et al., 2021; Nova Scotia Government, 2021).

Specialized FIT legislation helps prioritize local communities to develop renewable energy production capacity. This community renewable energy legislation is called community FIT (comFIT). Small or micro-scale energy (>10 MW) access legislation is called MicroFIT, which offers net-metering for houses. 


\section{Findings and Discussion}

Table 1 provides insights regarding the key factors shaping green renewable energy generation in Canada. The four factors are discussed at the provincial level to discuss what factors provide a just and sustainable transition to renewable energy and net-zero.

\subsection{Electricity Mix}

Table 1 shows that the energy mix of renewables for electricity varies greatly across the provinces. All provinces have some green renewables-from $0.5 \%$ in Newfoundland, to $15.8 \%$ in Nova Scotia and $98.9 \%$ in Prince Edward Island (PEI) electricity generation. About $30 \%$ of PEI's electricity needs are met by wind power, with PEI importing $60 \%$ of its power from New Brunswick and another $10 \%$ by other green renewables (Canada Energy Regulator, 2021). Without massive oil or hydro development, PEI and Nova Scotia, like New Brunswick at $10.2 \%$ and Ontario at $10.5 \%$, have shifted to green renewables from coal- and oil-fired power plants.

Green renewables are low in provinces where large-scale hydro and oil dominate. In contrast, green renewable amounts are lower, starting at $0.5 \%$ in Newfoundland, 2.9\% in Manitoba, 5.2\% in Quebec, and 8.1\% in British Columbia, where $90 \%+$ of electricity is from large hydro developments. Oil and gas continue to dominate in Alberta and Saskatchewan without much green renewable generation.

\subsection{Feed-in-Tariffs}

A critical factor in energy policy is prioritizing and guaranteeing grid access for renewable energy through feed-in-tariffs (FITs) (Mudasser et al., 2013). Ontario developed its FIT program in 2009 to promote private green renewable electricity generation, up to $500 \mathrm{~kW}$ capacity including on-shore wind, solar photovoltaic (PV), bioenergy (biomass, biogas and landfill gas) and small hydro-electricity. The FIT was also adopted by PEI as a "policy mechanism to encourage wind development” to reach 30\% of PEI's energy requirements by 2016 (CREA, 2016).

Nova Scotia has community FITS (comFITs) to assist community entities including municipalities, First Nations, energy co-operatives, and universities to own green renewable energy generation. Amherst's ComFIT program included 4550-panel community solar garden to power 240 homes and 700 electric vehicles with $2700 \mathrm{MWh} /$ year (Nova Scotia Department of Energy, 2021c). Furthermore, in 2021, community solar gardens were expanded to the towns of Berwick, Antigonish, and Mahone Bay, for a combined capacity of $8.8 \mathrm{MW}$ (Nova Scotia Department of Energy, 2021c). Other provinces have comFITS exclusive to First Nations but have limited green RETS otherwise.

Indigenous Clean Energy (ICE, 2022) lists 197 different projects that include mostly green renewable projects and energy efficiency projects. Also, these ICE projects also include a number of large hydro developments with impact benefit 
agreements or partnering. Most of the green renewable projects in Indigenous communities are wind projects located in Ontario, British Columbia, Nova Scotia and New Brunswick with some small hydro and solar in Ontario and British Columbia. Also, many biomass projects occur in First Nations in British Columbia. Quebec and Manitoba projects are mainly focused on a few large-scale hydro developments through partnerships with First Nations, while Saskatchewan and Alberta list only one green renewable project each (ICE, 2022).

Remote Indigenous communities have demanded a shift from diesel generation to energy security and ecojustice benefits. The shift to green renewables from diesel has been studied for decades in Canada but financing only became available recently. The "Indigenous off-diesel initiative" in 2019 launched a four year, \$20 million assistance with financial resources to develop and implement an ambitious diesel reduction plan (ICE, 2022). The Gull Bay First Nation in Ontario owns an integrated solar system that is offsetting $25 \%$ of polluting diesel fuel (110,000 litres) yearly (Kisik Clean Energy, 2022). The Saysai Dene are planning for wind and solar integration into the microgrid to offset $75 \%$ of diesel fuel/year, employ in ongoing operations five local people and reap $\$ 100,000$ yearly in revenue (Kisik Clean Energy, 2022).

\subsection{Renewable Energy Standard Offer Plans}

Four provinces, PEI, New Brunswick, Ontario and Nova Scotia, have pro-renewable economic factors and policies in progressive remuneration plans or RESOPs (Nishimura, 2012; Nova Scotia Government, 2021). These RESOPs have guaranteed rates and terms to make various renewable energy technologies categories and capacities a safe and solid investment. To attract capital and gain market share, RESOPs were created that have transparency, longevity and certainty in pricing to engage in a cycle of investment (Nova Scotia Department of Energy, 2021b).

Green energy technologies have recently become cost-competitive in an increasingly broad range of circumstances, including micro and small community levels (Silverstein, 2021). However, due to the low price of hydroelectricity, which has its infrastructure publicly subsidized in Canada, green renewables are less profitable than in other countries. For example, in 2021, Germany's electricity cost was US $\$ 0.37 / \mathrm{kWh}$ compared to Canada’s US $\$ 0.14 / \mathrm{kWh}$ (Statista, 2021a, 2021b, 2021c). This RESOP is about making the playing field fair.

\subsection{Renewable Energy Target}

The provinces with the highest renewable energy target are PEI at 100\% renewable energy (net-zero energy) by 2030 . Next highest isNova Scotia at $80 \%$ by 2030 , Quebec at $70 \%$ by 2025 , Ontario at $50 \%$ by 2023 and New Brunswick at $40 \%$ by 2023. Ontario, PEI, New Brunswick and Nova Scotia have positive factors of RESOP and FIT or ComFIT to facilitate reaching the green renewable goal.

Provinces with large-scale hydro have a different approach to renewable en- 
ergy targets. Quebec's target for renewables is met by large hydro being the great majority of its electricity generation, while offering microFITs by net metering homes. The three other provinces, British Columbia, Newfoundland and Manitoba, lack mid-term renewable energy target. These provinces have $90 \%+$ hydroelectrical generation but have limited green renewables. However, First Nation communities in British Columbia show many green renewable energy projects (ICE, 2022).

Provinces with rich oil and gas resources have little movement towards their renewable energy targets. Only in 2015 did Saskatchewan and Alberta declare RES targets, without any community power options (SaskPower, 2017; Saskatchewan Chamber of Commerce, 2019; Morales \& Jeyakumar, 2020), at 50\% and $30 \%$ respectively by 2030 (Alberta Government, 2020). Saskatchewan's high target of $50 \%$ by 2030 , is far away from its actual $16.8 \%$ renewable electricity, produced with $15.2 \%$ of that from large hydro development. Alberta's renewables at $9.1 \%$ are far away from the $30 \%$ target by 2030 . This gap between target and actual renewable energy is missing enabling policies, including FITs, comFITs and RESOPs to bridge the gap.

\section{Conclusion and Recommendation}

Canada's provinces have many factors that impact green renewable energy generation, which need analyzing to further green renewable opportunities. Most provinces with high renewable energy targets, namely PEI, Nova Scotia, Ontario and New Brunswick have enabling policies of RESOP and FIT or comFIT to facilitate reaching the green renewable goal. The other place green renewable energy transition is occurring is in Indigenous communities, dependent on diesel generation, to transition from colonial energy policy and its many negative impacts. Indigenous communities are looking for energy sovereignty with community energy benefits of jobs, revenues and energy security.

Those provinces with abundant oil and gas are slower to implement pro-renewable energy policies. Only in 2016 did Saskatchewan and Alberta declare RES targets, without any community power options (SaskPower, 2017; Morales \& Jeyakumar, 2020; Alberta Government, 2020; Alberta Government, 2021) and few results. Similarly, large-scale hydro development creates a lack of economic will to transition to renewable energy and implement the policies that result in change, including RETs, FITs or comFITs and RESOPs.

With the great benefit of decarbonizing electricity, fast-tracking net-zero electricity by 2035 should be required prioritizing community renewable energy through policies of RESOPs, RETs, FITs and comFITs. For the transportation and other sectors, banning of all fossil fuels before 2040 is needed. Rather than one big target of net-zero by 2050, clear milestones every five years are needed to shift policy rapidly. To reconcile the inequitable negative impacts of colonial energy policy, green renewable supports for Indigenous communities should be fast-tracked to create jobs, revenue, and energy security. Finally, a long-term 
plan to reduce impacts of hydro water fluctuation is needed, considering decommissioning some major dams having large negative impacts.

\section{Conflicts of Interest}

The author declares no conflicts of interest regarding the publication of this paper. This paper was funded by an SSHRC partnership grant.

\section{References}

Alberta Government (2020). Renewable Electricity Act. Renewable Electricity Act-Open Government.

https://www.qp.alberta.ca/1266.cfm?page=r16p5.cfm\&leg type=Acts\&isbncln=978077 $\underline{9814060}$

Alberta Government (2021). Renewable Energy Legislation and Reporting. Renewable energy Legislation and Reporting.

https://www.alberta.ca/renewable-energy-legislation-and-reporting.aspx

Canada (2022). Canada's Enhanced Nationally Determined Contribution under the Paris Agreement, 2021.

https://www4.unfccc.int/sites/ndcstaging/PublishedDocuments/Canada\%20First/Cana da\%27s\%20Enhanced\%20NDC\%20Submission1 FINAL\%20EN.pdf

Canada Energy Regulator (CER) (2021). Canada's Renewable Power. https://www.cer-rec.gc.ca

Canada's National Observer (2021). Canadian Town First to Pledge Net-Zero Emissions by 2030.

https://www.nationalobserver.com/2021/12/02/news/canadian-town-first-pledge-net-z ero-emissions-2030

Chestney, N., Lewis, B., \& Jones, G. (2021). Reuters-Environment. https://www.reuters.com

CREA, Canadian Renewable Energy Association (2016). Canada's Renewable Power Landscape 2016-Energy Market Analysis. CREA.

https://www.cer-rec.gc.ca/en/data-analysis/energy-commodities/electricity/report/2016 -canadian-renewable-power/province/canadas-renewable-power-landscape-2016-energ y-market-analysis-new-brunswick.html

CREA, Canadian Renewable Energy Association (2020). Wind, Solar Storage. https://www.renewablesassociation.ca

Dusyk, N., Turcotte, I., Gunton, T., MacNab, J., McBain, S., Penney, N., Pickrell-Barr, J., \& Pope, T. (2021). All Hands on Deck: An Assessment of Provincial, Territorial and Federal Readiness to Deliver a Safe Climate. Pembina Institute. https://www.pembina.org/pub/all-hands-on-deck

Eckert, V., \& Nasr, J. (2021). Germany Hits Renewable Accelerator, Targets Coal Exit by 2030.

https://www.reuters.com/markets/commodities/german-coalition-commits-faster-deca rbonisation-2021-11-24/

Fraser, M. (2008). Why RFPs Don't Work. World Wind Energy Conference Proceedings, (pp. 1-5), Kingston.

Government of Canada (2021). What's in Canada's Climate Plan? Net-Zero by 2050. https://www.canada.ca/en/services/environment/weather/climatechange/climate-plan/ climate-plan-overview.html 
Government of Ontario (2017). Ontario Climate Change Action Plan. https://www.ontario.ca/page/climate-change-action-plan

Gregory, P. (2017). 100\% Renewables by 2015. Forbes. https://www.forbes.com/sites/uhenergy/2017/03/31/100-renewables-by-2050-germanypays-the-price-for-its-ambition/\#416c69df1e98

Indigenous Clean Energy (ICE) (2022). Indigenous Clean Energy. https://indigenouscleanenergy.com/

International Energy Agency (IEA) (2021). Net-Zero by 2050-A Road Map for the Global Energy Sector. IEA. . https://www.iea.org/reports/net-zero-by-2050

International Institute of Sustainable Development (IISD) (2022). Finding the Way to Zero: Final Report of Climate Action Network Canada's 2021 Workshop Series on Net-Zero.

https://www.iisd.org/system/files/2022-01/climate-action-network-canada-2021-works hop-series-net-zero-en.pdf

International Renewable Energy Agency (IRENA) (2021). https://www.irena.org/energytransition

Kisik Clean Energy (2022). Projects-Gull Bay First Nation Micro Grid Project. https://www.kisikcleanenergy.com/projects

Koval, V., Sribna, Y., Kaczmarzewski, S., Shapovalova, A., \& Stupnytskyi, V. (2021). Regulatory Policy of Renewable Energy Sources in the European National Economies. Polityka Energetyczna-Energy Policy Journal, 24, 61-78. https://doi.org/10.33223/epj/141990

Lappe, F. (2021). It's Not Too Late! Crisis, Opportunity, and the Power of Hope. https://f19bcfcc-2c42-4b12-af8d-be6ea6bd5fad.filesusr.com/ugd/45eb90 9cca8babf515 453090ffd78151ab43bf.pdf

Lior, N. (2010). Sustainable Energy Development: The Present (2009) Situation and Possible Paths to the Future. Energy Journal, 35, 3976-3994. http://www.sciencedirect.com/science/article/pii/S0360544210001532 https://doi.org/10.1016/j.energy.2010.03.034

Mendonça, M., Jacobs, D., \& Savacool, B. (2009). Powering the Green Economy: The Feed-In Tariff Handbook. Earthscan.

Morales, V., \& Jeyakumar, B. (2020). Renewable Energy-What You Need to Know. Pembina Institute. http://www.jstor.org/stable/resrep28320

Mudasser, M., Yiridoe, E. K., \& Corscadden, K. (2013). Economic Feasibility of Large Community Feed-In Tariff-Eligible Wind Energy Production in Nova Scotia. Energy Policy, 62, 966-977. https://doi.org/10.1016/j.enpol.2013.07.108

National Energy Board of Canada (NEBC) (2015). Energy Information Program. National Energy Board. http://www.neb-one.gc.ca/nrg/prgrm-eng.html\#fnb1

National Energy Board of Canada (NEBC) (2016). Canada's Renewable Power Landscape 2016-Energy Market Analysis.

https://www.cer-rec.gc.ca/en/data-analysis/energy-commodities/electricity/report/2016 -canadian-renewable-power/canadas-renewable-power-landscape-2016-energy-market -analysis-canadian-overview.html

Nishimura, K. (2012). Grassroots Action for Renewable Energy: How Did Ontario Succeed in the Implementation of a Feed-In Tariff System? Energy, Sustainability and Society, 2, Article No. 6. https://doi.org/10.1186/2192-0567-2-6

Nova Scotia Department of Energy (2021a). Electricity Act. https://www.novascotia.ca

Nova Scotia Department of Energy (2021b). Nova Scotia Renewable Electricity Regula- 
tions. https://www.novascotia.ca/Just/Regulations/regs/elecrenew.htm

Nova Scotia Department of Energy (2021c). Solar Gardens Coming to Antigonish, Berwick and Mahone Bay. https://novascotia.ca/news/release/?id=20210708003

Nova Scotia Government (2020). Renewable Energy Facts. https://www.nrcan.gc.ca

Nova Scotia Government (2021). Province Invests in Climate Change Action, Supports Jobs and Commits to Renewable Future. https://novascotia.ca/news/release/?id=20210224001

Saskatchewan Chamber of Commerce (2019). The Renewable Energy Sector in Saskatchewan.

https://saskchamber.com/isl/uploads/2019/04/State-of-Renewable-Energy-in-Saskatche wan.pdf

SaskPower (2017). The Path to 2030: SaskPower Updates Progress on Renewable Electricity.

https://www.saskpower.com/about-us/media-information/news-releases/2018/03/the-p ath-to-2030-saskpower-updates-progress-on-renewable-electricity

Scottish Government (2021). Onshore Wind-Policy Statement Refresh 2021: Consultative Draft.

https://www.gov.scot/publications/onshore-wind-policy-statement-refresh-2021-consu ltative-draft/pages/2/

Scottish Renewables (2021). Green Jobs: The Job Board for Green Experts.

https://www.greenjobs.co.uk/scottish-renewables.cms.asp

Silverstein, K. (2021). Can We Stop Stressing Over the Green Energy Transition-It Is Bearing Fruit.

https://www.forbes.com/sites/kensilverstein/2021/07/01/can-we-stop-stressing-over-th e-green-energy-transition---it-is-bearing-fruit/?sh=32b2bd0cfde8

Statista (2021a). Household Electricity Prices Worldwide in December 2020, by Select Country (in U.S. Dollars per Kilowatt Hour).

https://www.statista.com/statistics/263492/electricity-prices-in-selected-countries/

Statista (2021b). Electricity Cost for End-Users in Canada 2021, by Province and Territory (in Canadian Cents per 1,000 Kilowatt Hours).

https://www.statista.com/statistics/516279/electricity-costs-for-end-users-canada-by-pr ovince/

Statista (2021c). Share of Wind Power Coverage in Denmark from 2009 to 2020. https://www.statista.com/statistics/991055/share-of-wind-energy-coverage-in-denmark/

Sturgeon, N. (2021). The Environment. Scotland's Electricity Consumption Isn't 100\% Renewable. https://www.fullfact.org

Thompson, S. (2015). Flooding First Nations and Environmental Justice in Manitoba: Case Studies of the Impacts of 2011 Flood and Hydro Development in Manitoba. Manitoba Law Journal, 38, 220-259

TREC (2016). The Power of Community. http://www.trec.on.ca/wp-content/uploads/2016/06/TREC Primer Jun28 Approved Final-LR.pdf

United Nations (UN) (2021). Theme Report on Energy Transition-Towards the Achievement of SDG 7 and Net-Zero Emissions.

https://www.un.org/sites/un2.un.org/files/2021-twg_2-062321.pdf

USEPA (2016). Green Power Markets. http://www.epa.gov/greenpower/gpmarket/ 